\title{
Assessing Domains in Quality of Life-A Case Study
}

\author{
Sayanti Sen1, Goutam Sen² \\ ${ }^{1}$ Department of Geography, Bangabasi College, Calcutta University, Kolkata, India \\ ${ }^{2}$ School of Oceonographic Studies, Jadavpur University, Kolkata, India \\ Email: sayantisen ju@yahoo.co.in, gksju@yahoo.co.in
}

Received 14 September 2014; revised 12 October 2014; accepted 8 November 2014

Copyright (C) 2014 by authors and Scientific Research Publishing Inc.

This work is licensed under the Creative Commons Attribution International License (CC BY). http://creativecommons.org/licenses/by/4.0/

(c) (i) Open Access

\begin{abstract}
Mining in India has developed haphazardly with a significant part of mining activities being informal or unauthorised. Open cast quarries, coal washeries, thermal power plants, coke-oven plants, etc., contribute to serious air and water pollution. The aim of this paper is to assess the QoL of residents living in Jharia coalfield. In this study, QoL domains are analysed considering the social, cultural, environmental, health and economic condition of the study areas. A path model has been developed to analyse the cascading effect on domains. The purpose of investigating path model with overall quality of life was to contribute to the subjective wellbeing literature by analyzing the predictors of OQoL in the sample population. Therefore, OQoL was used as the dependent variable of a regression analysis using four domains as variables and leveraging path analysis method to arrive at the causal model.
\end{abstract}

\section{Keywords}

Quality of Life, Path Analysis, Minning, Jharia

\section{Introduction}

Mining in India has developed haphazardly with a significant part of mining activities being informal or unauthorised mining. Open cast quarries, coal washeries, thermal power plants, coke-oven plants, etc., contribute to serious air and water pollution. [1]-[3] mentioned of issues confronting with achieving desired development for economic or social reasons and as a result, persisting degradation of health, safety and wellbeing has been affecting quality of life. The region continues to witness serious ecological imbalance and associated environmental problems [4]. Fire and subsidence due to atrocious mining practices are some of the reasons which make such mining areas vulnerable; these areas are of grave concern and these have directly attributed to unscientific and 
unplanned coal mining in these areas. The magnitude of the problem has increased over the years with growth of habitation over unsafe areas.

As documented a number of mining activities impact environmental, health and safety problems, each of which adversely impacts human quality-of-life [5] [6] have studied QoL to plan for overall community development. [7]-[10] studied quality of life indexing system of Bhowra mine area and West Bokaro complexes in Jharkhand to identify the degrading situation of inhabitants' lifestyle prevalent in the area. Human quality of life was studied for Bokaro mining complex by [11] and for Jharia coalfield by [12] and QoL was quantified on the basis of resident's economic capability. The impact of [13] mine fire and subsidence on QoL in Jharia coalfield area and provided rehabilitation and relocation plan for the region. The issues confronting today are faced with achieving desired development for economic or social reasons on one hand and safeguarding the environment and maintaining good QoL on the other [5].

The aim of this paper is to assess the QoL of residents living in Jharia coalfield. In this study, QoL domains are analysed considering the social, cultural, environmental, health and economic condition of the study areas. An interpretation of QoL indicators and domains has been presented while measuring QOL. A path model has also been developed to analyse the cascading effect on other domains. The purpose of investigating path model with overall quality of life was to contribute to the subjective wellbeing literature by analyzing the predictors of OQoL in the sample population. Therefore, OQoL was used as the dependent variable of a regression analysis using four domains as variables and leveraging path analysis method to arrive at the causal model.

The study area lies in the heart of Damodar valley along the north of Damodar River in the eastern part of India as seen in Figure 1.

The coalfield is named Jharia, situated in the eastern part of DRB, extends for about $38 \mathrm{~km}$ in the east-west direction and a maximum of $18 \mathrm{~km}$ in the north-south direction covering an area of about $450 \mathrm{sq} . \mathrm{km}$ and is a representative area of the whole DRB [5]. Jharia coalfield, is located in Dhanbad district of Jharkhand state which lies between $23^{\circ} 37^{\prime} 3 " \mathrm{~N}$ and $24^{\circ} 4^{\prime} \mathrm{N}$ latitude and between $86^{\circ} 6^{\prime} 30^{\prime \prime} \mathrm{E}$ and $86^{\circ} 50^{\prime} \mathrm{E}$ longitude. Jharia situated in the eastern part of the coal field extends for about $38 \mathrm{~km}$ in the East West direction and $18 \mathrm{~km}$ in North South direction covering of about $450 \mathrm{~km}^{2}$ [14].

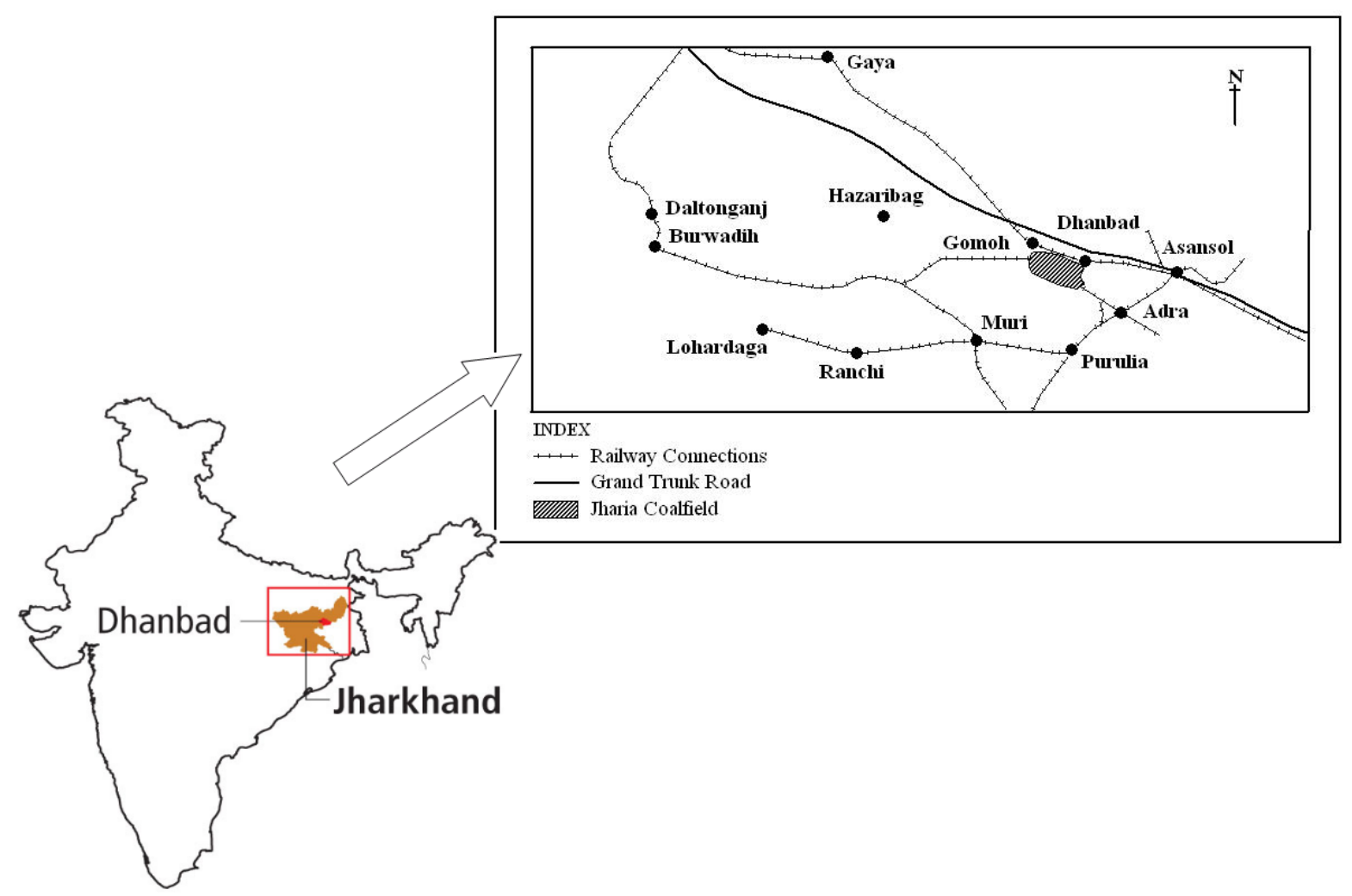

Figure 1. Study area. 


\section{Methodology}

The methodological strategy chosen for this study is a case study approach and includes a combination of quantitative sources of evidence. The pre-tested self evaluating questionnaire was used to document the satisfactory levels of respondents residing in the core and buffer zones of the mining area. This questionnaire consisted of The sample survey was conducted covering about 70 households belonging to different caste-groups, occupation-groups and land size-groups to make it approximate to a stratified sampling method. Analysis of the acquired data has been done leveraging existing literature and validation using statistical techniques.

\subsection{Interpreting Quality of Life}

The survey was organized to collect information on key facets of home and environment variables at the household level. Besides making an analysis on aspects of living conditions and socioeconomic profile, environmental satisfaction, social and civil aspects of life satisfaction of the locality, an attempt has also been made to analyze the overall quality of life in the existing mining region.

For interpreting the quality of life of the study area, the data has been stratified by a 5-point scale of QoL assuming a normal distribution. The 5-point scale is defined as follows:

1) Significantly below Average QOL - values between $\mu-3 \sigma$ and $\mu-2 \sigma$.

2) Below Average QOL - values between $\mu-2 \sigma$ and $\mu-\sigma$.

3) Average QOL - values between $\mu-\sigma$ and $\mu+\sigma$.

4) Above Average QOL - values between $\mu+\sigma$ and $\mu+2 \sigma$.

5) Significantly above Average QOL - values between $\mu+2 \sigma$ and $\mu+3 \sigma$.

where $\mu=$ mean value and $\sigma=$ standard deviation.

After stratifying the satisfaction score, a detailed analysis was done to investigate the cross-sectional factors to identify the sections of population whose QoL is directed by the parameters which are considered for assessing quality of life in various domains of life. The data have been categorically analyzed to detail the quality of life of the respondents in the study area. As part of the questionnaire a single question was asked to the respondents about an overall quality of life measure "Your Overall Quality of Life?".

\subsection{Path Analysis for Overall Quality of Life (OQoL)}

Having isolated four domains which influence the QoL, it was also found that a causal relationship needed to be established. As part of the questionnaire a single question was asked to the respondents about an overall quality of life measure "Your Overall Quality of Life?".

The Total QoL score for the respondents is an aggregation of the scores in the individual domains namely economic liberty, environmental liberty, community liberty and civil liberty. Many researchers in their work have impressed upon the need for measuring overall quality of life as a singular question to respondents and its correlation with the total quality of life score. As highlighted in the Table 1 the total quality of life score has strong correlation $(r=0.716)$ with the OQoL score.

Path analysis is a straight forward extension of multiple regression which aims to provide estimate of the magnitude and significance of hypothesized causal connections between sets of variables. The arrows indicate that the variable at the tail of the arrow affects the variable at the head of the arrow. The numbers on the arrows are the path coefficients and indicate the strength of the relationship. OQoL is the final dependent variable.

During the study multiple path models were developed and tested for correlation between the input domain parameters and the OQoL dependant variable. Figure 2 shows the evolution of path model. The equation below has been used to calculate the path coefficient:

$$
Z_{0}=P_{01} Z_{1}+P_{02} Z_{2}+P_{03} Z_{3}+P_{04} Z_{4}
$$

The path models were tested for correlation between the domains and the causal output of overall quality of life. Model 3 with causal relationship between economic liberty domain and other 3 domains showed the highest correlation value and the path coefficients are highlighted.

The overall effect on OQoL is a cumulative of direct effects and indirect effects. Each direct effect in the path diagram should be interpreted as the amount of change in a dependent variable due to a unit change in independent variable if no effects are transmitted through intervening variables. Indirect effects, on the other hand has been calculated and interpreted as the magnitude of the predicted change in the dependent variables through in- 
Table 1. Correlation among dependent variables.

\begin{tabular}{|c|c|c|c|c|c|c|}
\hline \multirow{2}{*}{ Correlation } & \multicolumn{5}{|c|}{ Domain Wise Quality of Life Score } & \multirow{2}{*}{ OQoL } \\
\hline & Economic Liberty & Environmental Liberty & Community Liberty & Civil Liberty & Total QoL & \\
\hline Economic Liberty & - & 0.312 & 0.357 & 0.457 & 0.899 & 0.665 \\
\hline Environmental Liberty & & - & 0.226 & 0.214 & 0.590 & 0.557 \\
\hline Community Liberty & & & - & 0.279 & 0.563 & 0.301 \\
\hline Civil Liberty & & & & - & 0.631 & 0.304 \\
\hline Total QoL & & & & & - & 0.716 \\
\hline
\end{tabular}

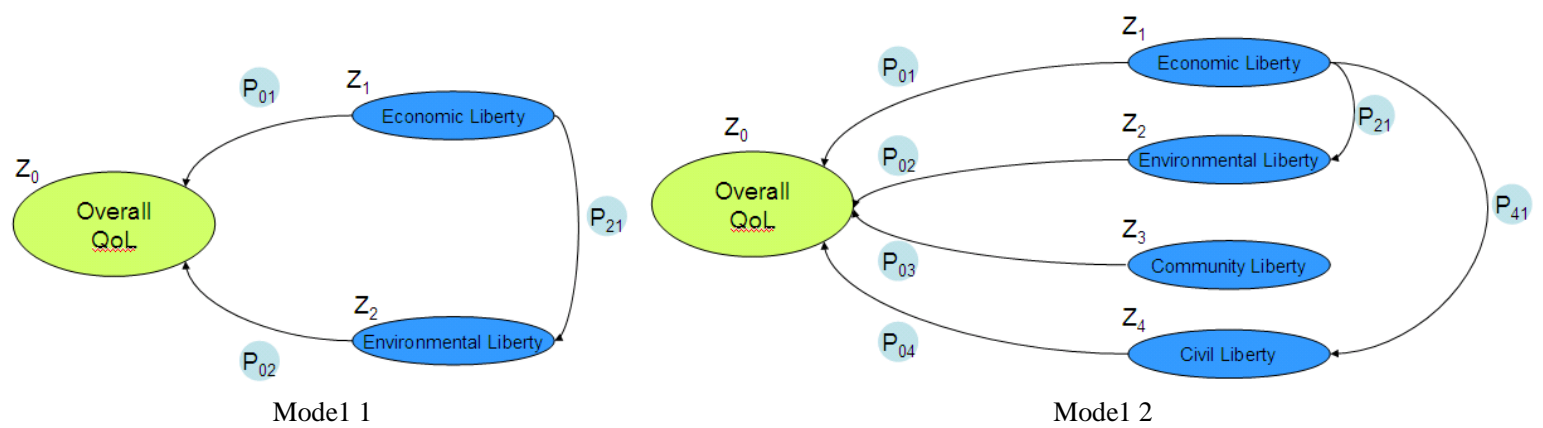

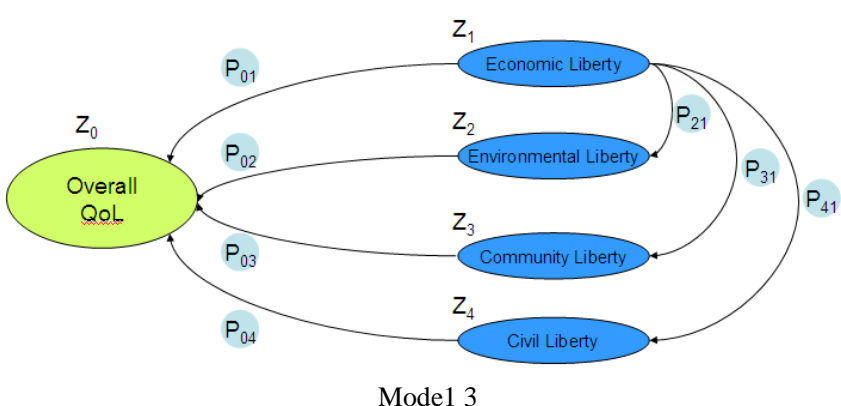

Mode1 3

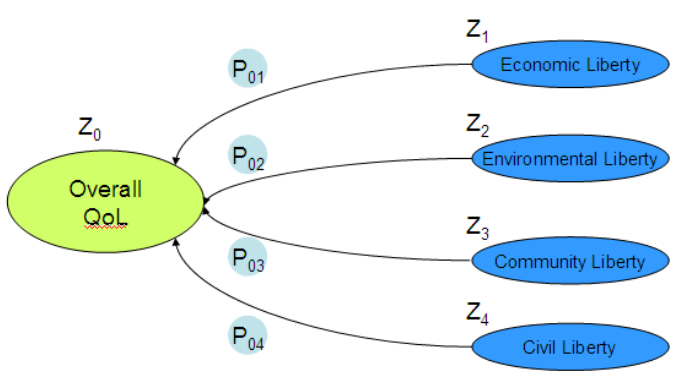

Mode1 4

Figure 2. Evolution of path model. Model 1: This is a simplistic model where OQoL is determined only by economic and environment domains with the environmental domain being influenced by the economic domain. These 2 domains were chosen as they have moderately high levels of correlation with OQoL. Model 2: 2 remaining domains are included in the analysis and causal relationship between Economic and Civil domains is added. Amongst the 4 domains, Economic and Civil domains have the highest correlation. Model 3: Causal relationship between Economic and other 3 domains is hypothesized. Model 4: All domains are considered to be independent with either no correlation or with no causal relationship between them.

tervening variables if the independent variables is changes one unit. Indirect effect can be calculated by multiplying path coefficient for compound causal paths.

Direct effect of economic liberty domain $=P_{01}$

Indirect effect of economic liberty domain on OQoL is computed as a summation of the following components:

- $\quad$ economic $>$ environment $>\mathrm{OQoL}=P_{21} P_{02}$.

- $\quad$ economic $>$ community $>$ OQoL $=P_{31} P_{03}$.

- economic $>$ civil $>$ OQoL $=P_{41} P_{04}$.

Hence indirect effect $=\left(P_{21} P_{02}\right)+\left(P_{31} P_{03}\right)+\left(P_{41} P_{04}\right)$

Total effect $=$ Direct effect + Indirect effect $=P_{01}+\left(P_{21} P_{02}\right)+\left(P_{31} P_{03}\right)+\left(P_{41} P_{04}\right)$ 


\section{Results and Discussions}

The section represents relationship among the factors related to QoL to lay emphasis on providing better services to the locality and enhance the QoL of the people. The analysis was done in the following steps:

- The total respondent population was stratified based on the total satisfaction score by a 5-point scale assuming normal distribution.

- The overall data is analysed by demographic parameters like sex, age, housing status etc. as per the 5-point scale.

- The data was then analysed by the 4 defined domains and their sub-parameters.

- Detailed analysis of domain level strengths and impact on Total QoL.

- Correlation between the QoL domains, Total QoL and Overall QoL was determined.

\subsection{Analysis of Quality of Life of Surveyed Population}

For interpreting the QoL of the study area, firstly the mean score was calculated which is 83.97 and deviation from the mean is 13.48. The lower limit of QoL and higher limit of QoL was calculated subtracting the deviation from the mean to get the lower and higher limit. Figure 3 shows the spatial pattern of quality of life. The Table 2 summarizes the distribution of the respondents as per the 5-point scale.

\subsection{Analysis of Quality of Life Based on Demographic Information}

\subsubsection{Sex Ratio}

For this study the sample population was 70 among the sample respondents $10 \%$ females, and $90 \%$ interviews were males.

From Table 3, it is noted that none of the female respondents interviewed reported of having "Above Average" QoL. This might be attributed to the fact that the women population in the surveyed area are from economically backward parts of the society and have nominal influence upon the four liberty domains. $29 \%$ of female respondents reported of having "Below Average" QoL whereas 71\% have an average QoL as shown in Figure 4.

Detailed analysis showed that in economic liberty domain, women have satisfaction levels equally between "Below Average and 'Average' while in Environmental and community liberty domains the female respondents have an 'average' QoL. For civil liberty domain, they have a mixed satisfaction levels of QoL. It has been noted that life satisfaction perception response from male respondents have been ranging from Below Average to significantly Above Average. With maximum of 70\% men having average QoL and 6\% male respondents reported of having significantly Above Average QoL. Men with a 'Significantly above Average' in economic liberty domain have an overall QoL 'Significantly above Average’”.

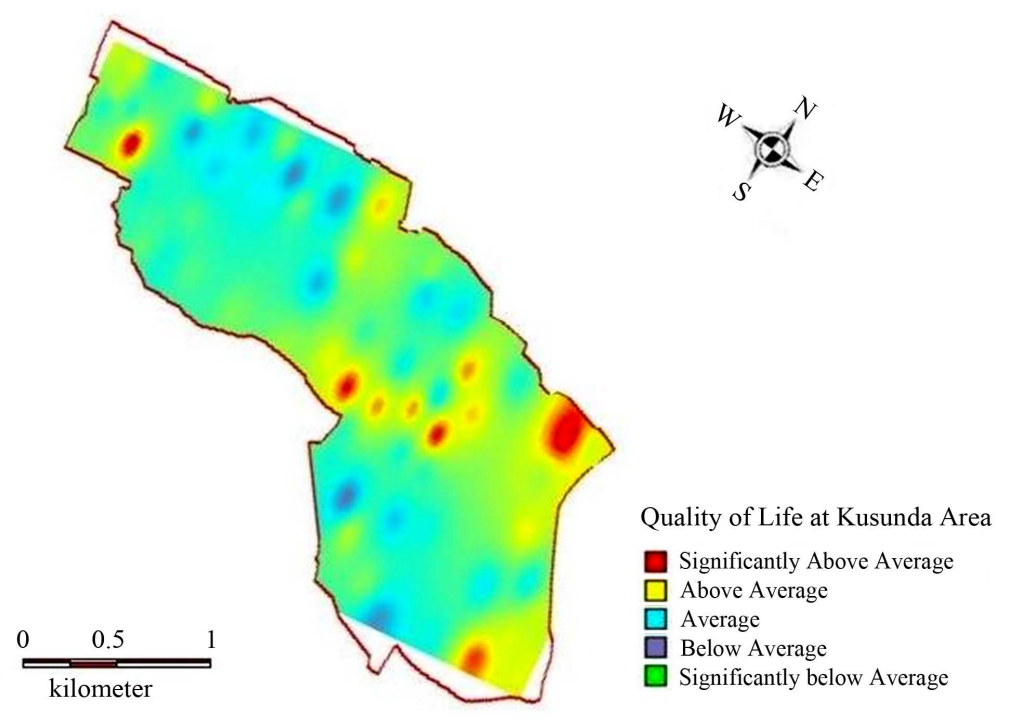

Figure 3. Quality of life at Kusunda area of Jharia Coalfields. 
Table 2. Developing the 5-point scale for analysing quality of life scores using a normal distribution.

\begin{tabular}{|cccc}
\hline \multirow{2}{*}{ 5-Point Scale } & \multicolumn{2}{c}{ QoL Score } & Distribution in (\%) \\
\cline { 2 - 3 } & Lower Limit & Higher Limit & \\
\hline Significantly below Average QoL & 43.5 & 57.0 & 0.0 \\
Below Average QoL & 57.0 & 70.5 & 5.70 \\
Average QoL & 70.5 & 97.4 & 70.00 \\
Above Average QoL & 97.4 & 110.9 & 8.60 \\
Significantly above Average QoL & 110.9 & 124.4 & 5.70 \\
\hline
\end{tabular}

Table 3. Quality of life by sex ratio.

\begin{tabular}{cccccc}
\hline \multirow{2}{*}{ Sex Ratio } & \multicolumn{5}{c}{ Quality of Life } \\
\cline { 2 - 6 } & $\begin{array}{c}\text { Significantly } \\
\text { below Average }\end{array}$ & $\begin{array}{c}\text { Below } \\
\text { Average }\end{array}$ & Average & $\begin{array}{c}\text { Above } \\
\text { Average }\end{array}$ & $\begin{array}{c}\text { Significantly } \\
\text { above Average }\end{array}$ \\
\hline Overall Population & $0 \%$ & $15.7 \%$ & $70.0 \%$ & $8.6 \%$ & $5.7 \%$ \\
Female & $0 \%$ & $29 \%$ & $71 \%$ & $0 \%$ & $0 \%$ \\
Male & $0 \%$ & $14 \%$ & $70 \%$ & $10 \%$ & $6 \%$ \\
\hline
\end{tabular}

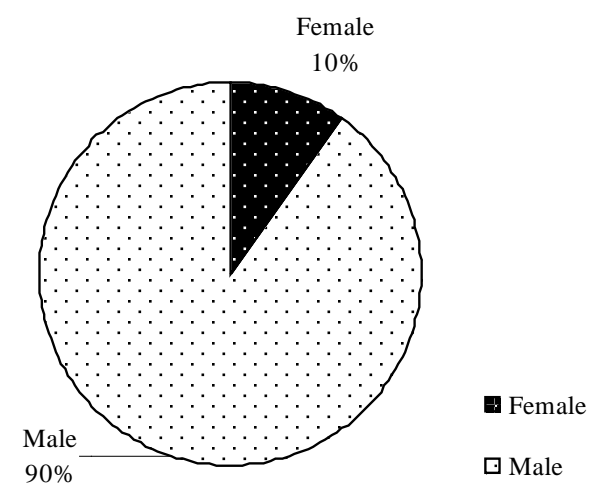

Figure 4. Age-sex ratio.

\subsubsection{Age and Quality of Life}

The demographic composition of sample population taken into consideration is distributed between the age group 25 years to more than 60 years. The age-group spread of the sample population is shown in the Figure 5 with 77\% of the population covered between 25 - 50 age groups who are among the prime working groups.

A further investigation about the QoL of the above respondents it reveals (Table 4) that $12 \%$ of the $31-40$ age group respondents responded with a QoL "Significantly above Average" and in 41 - 50 age group, the "Significantly above Average" QoL population drops to 5\%. The 25 - 30 and 41 - 50 age group responded with the highest "Average" scores of $78 \%$ and $79 \%$ respectively. The 51 - 60 age groups scored the maximum "Above Average" scores.

The analysis above corroborates the ground reality in India context where 25 - 30 age group struggles for a job and a living while 31 - 40 age group is where there is maximum assertion of youth in Economic, Community, Environmental and civil liberty domain areas and thereafter it degrades with increasing age due to socio-economic dependence on children and lack of social security norms.

\subsubsection{Land Ownership Status and Quality of Life}

The respondents land ownership status and QoL were assessed keeping in mind the vulnerability of the study 
Table 4. Age-wise distribution.

\begin{tabular}{cccccc}
\hline $\begin{array}{c}\text { Age-Wise } \\
\text { Distribution (in Years) }\end{array}$ & \multicolumn{5}{c}{ Quality of Life } \\
\cline { 2 - 6 } & Significantly below Average & Below Average & Average & Above Average & Significantly above Average \\
\hline Overall Population & $0 \%$ & $15.7 \%$ & $70.0 \%$ & $8.6 \%$ & $5.7 \%$ \\
$25-30$ & $0 \%$ & $11 \%$ & $78 \%$ & $11 \%$ & $0 \%$ \\
$31-40$ & $0 \%$ & $23 \%$ & $65 \%$ & $0 \%$ & $5 \%$ \\
$41-50$ & $0 \%$ & $11 \%$ & $79 \%$ & $5 \%$ & $0 \%$ \\
$51-60$ & $0 \%$ & $8 \%$ & $58 \%$ & $33 \%$ & $0 \%$ \\
\hline
\end{tabular}

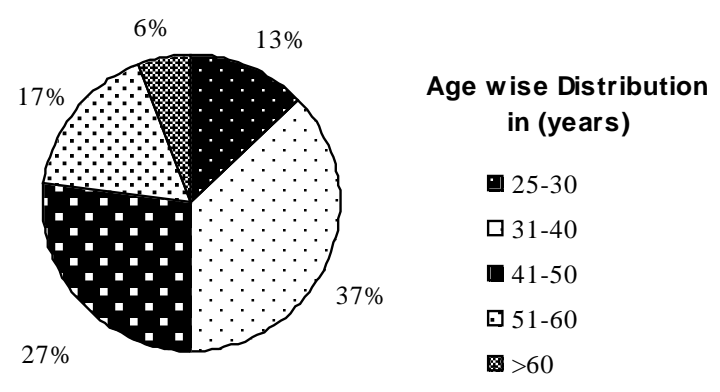

Figure 5. Age-wise distribution.

area due to mine fire and its economical viability making the region danger-prone for the residents to occupy. The study area is very much in news due to the fact that government at its different forums have been discussing for the evacuation of the area as a large portion is under fire, subsidence and inundation. The residents of the study area are not ready to evacuate the place as they earn their living from the surroundings which has developed into a good commercial hub. Three categories of ownership status ascertain in the study region. 54\% of the respondents were found to be encroachers and the rest $44 \%$ were distributed among the legal land holders and tenants.

A further investigation about the QoL of the respondents land ownership it was seen that (Table 5) that 80\% of the legal land holder have reported to have “Average” QoL while 10\% each are "Below Average QoL” and “Above Average QoL”. 5\% tenant and 8\% encroacher are the only category of people flaunting to have "Significantly above Average” QoL.

Figure 6 shows the analysis above establishes the respondents who own a legal land holding are devoid of "Significantly above Average” QoL. It appears that with more security, as in case of ownership of land holding, comes an additional cost of maintaining it due to continues risk of subsidence, fire and fear of loosing the land probably negatively impacts QoL satisfaction level Table 5 shows the variation below.

\subsubsection{Housing Status and Quality of Life}

In the mining region, a lot of land is illegally mined by private contractors. Besides, land is also converted into roads, townships for miners, infrastructure for administrative purposes, stockyard for preliminary processing operations, etc. Keeping with the inclination for illegal mining practices residents of the region, it was seen that $40 \%$ respondents have illegal housing, 46\% rented housing and 14\% owned houses. The booming coal based industrial economy has not only made the region a striking location for easy money making but also a lucrative region for several illegal activities. The housing pattern with $40 \%$ illegal housing is not a surprise.

The study area's socio-economics included an assessment of the coalfield area, a proposed rehabilitation strategy and a cost-benefit analysis for relocation and rehabilitation of affected people [15].

With a history of subsidence, the region has been identified as one of the risk prone regions inundated with problems like land acquisitions, and an active underground coal mine fire. Such problems are caused due to haphazard growth of population resulting to such incompatible housing status. As shown in Figure 7 people own- 
Table 5. Ownership status of land.

\begin{tabular}{cccccc}
\hline \multirow{2}{*}{$\begin{array}{c}\text { Ownership } \\
\text { Status of Land }\end{array}$} & \multicolumn{5}{c}{ Quality of Life } \\
\cline { 2 - 6 } & Significantly below Average & Below Average & Average & Above Average & Significantly above Average \\
\hline Overall Population & $0 \%$ & $15.7 \%$ & $70.0 \%$ & $8.6 \%$ & $5.7 \%$ \\
Encroacher & $0 \%$ & $16 \%$ & $66 \%$ & $11 \%$ & $8 \%$ \\
Legal Land Holder & $0 \%$ & $10 \%$ & $80 \%$ & $10 \%$ & $0 \%$ \\
Tenant & $0 \%$ & $18 \%$ & $73 \%$ & $5 \%$ & $5 \%$ \\
\hline
\end{tabular}

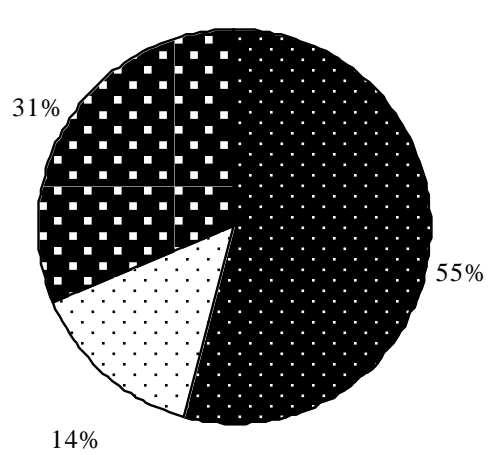

\author{
Ownership Status \\ Encroacher \\ $\square$ Legal land Holder \\ - Tenant
}

Figure 6. Land ownership status.

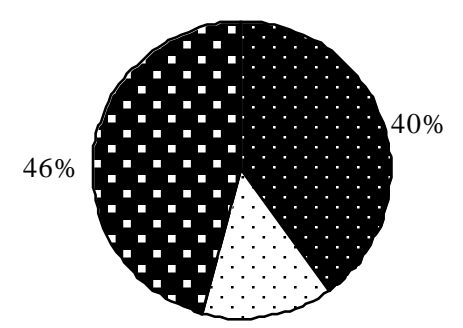

$14 \%$

\section{Housing Status}

- Ilegal housing

$\square$ Owned Housing

Eented Housing

\title{
Figure 7. Housing status.
}

ing their housing do not have "Significantly above Average" QoL and may be attributed to higher cost of living. Table 6 shows However, 80\% of the people owning houses reported “Average” QoL, the highest in all groups. The cost of living for rented yet legal housing is probably lower than for self owned housing and is a better option than illegal housing status.

\subsubsection{Duration of Stay and Quality of Life}

Human being does things which interests him and benefits the society. Hence, the impacts of the human activities, specially mining and associated activities, on the society assume a great importance on his stay in the community. The people of the mineral bearing areas, with the advent of mining and associated activities, are exposed to various developments and this tends to increase their aspiration for employment and better their wellbeing. It was noted from the sample of 70 respondents about $84 \%$ of the respondents are residents of the study area for more than 15 years.

Healthy human communities are an integral part of a society. The duration of stay of the population in the mineral rich industrialized community is a major driving factor to healthiness and well-being. From Table 7 and Figure 8 it is analysed that $100 \%$ of the respondents whose duration of stay is less than 10 years have Average QoL and their age group suggests that they have migrated to the study area potentially for an occupation. The 
Table 6. Housing status.

\begin{tabular}{cccccc}
\hline \multirow{2}{*}{ Housing Status } & \multicolumn{5}{c}{ Quality of Life } \\
\cline { 2 - 6 } & Significantly below Average & Below Average & Average & Above Average & Significantly above Average \\
\hline Overall Population & $0 \%$ & $15.7 \%$ & $70.0 \%$ & $8.6 \%$ & $5.7 \%$ \\
Illegal Housing & $0 \%$ & $14 \%$ & $64 \%$ & $14 \%$ & $7 \%$ \\
Owned Housing & $0 \%$ & $10 \%$ & $80 \%$ & $10 \%$ & $0 \%$ \\
Rented Housing & $0 \%$ & $19 \%$ & $72 \%$ & $3 \%$ & $6 \%$ \\
\hline
\end{tabular}

Table 7. Duration of stay in the community and quality of life.

\begin{tabular}{|c|c|c|c|c|c|}
\hline \multirow{2}{*}{$\begin{array}{l}\text { Duration of Stay } \\
\text { in the Community } \\
\text { (in Years) }\end{array}$} & \multicolumn{5}{|c|}{ Quality of Life } \\
\hline & Significantly below Average & Below Average & Average & Above Average & Significantly above Average \\
\hline Overall Population & $0 \%$ & $15.7 \%$ & $70.0 \%$ & $8.6 \%$ & $5.7 \%$ \\
\hline$<10$ & $0 \%$ & $0 \%$ & $100 \%$ & $0 \%$ & $0 \%$ \\
\hline $10-15$ & $0 \%$ & $25 \%$ & $38 \%$ & $13 \%$ & $25 \%$ \\
\hline $15-20$ & $0 \%$ & $22 \%$ & $78 \%$ & $0 \%$ & $0 \%$ \\
\hline$>20$ & $0 \%$ & $14 \%$ & $72 \%$ & $10 \%$ & $4 \%$ \\
\hline
\end{tabular}

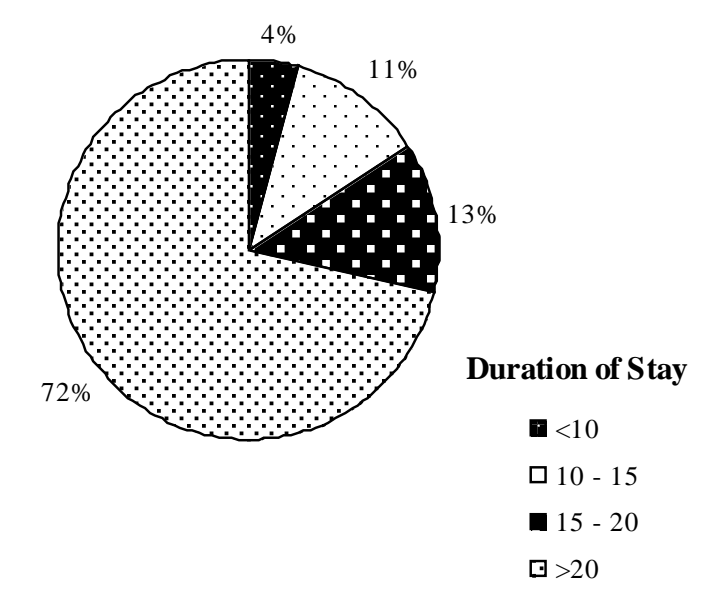

Figure 8. Duration of stay in the community.

percentage of population living between 15 - 20 years reports to have a high 78\% population with "Average" QoL and 22\% with "Below Average" QoL. We all know that the region have fashioned several big and small coal businessmen as well as illegal miners due to the regions capability to make coal into free flowing money.

Apparently the percentage of population living in this region for more than 20 years have the flavour of mining activities which have brought immediate capital to a region and restructured their activities and communities into a mining-dependent region. Consequently in this category, $4 \%$ the total population are reported to have significantly above average QoL, 10\% above average QoL. Incidentally, 25\% of the population staying between 10 - 15 years has significantly above average QoL.

\subsubsection{Distribution of Occupation}

The development of industrial and other associated activities in this area have increased the level of the economic activities creating several job opportunities; with labour supply has never been a problem for industrial expansion. Increased industrial and economic activities generate more money and increase the buying power of the people directly and indirectly associated with these activities. This leads to an increase in the cost of living, 
and it is believed that economic stability brings in satisfaction in human wants. The 1:2 ratios between the self employed (62\%) and daily wage labour (33\%) gives an idea regarding various job opportunities that reflect the ability to search work locally, types and nature of work available. In this region informal mining is an unofficial and unsanctioned often labelled as illegal mining. Percentage of self-employed can be an indicator of entrepreneurial drive of the workforce, but also be dominated by depressed and underemployed workers.

In regions like Jharia, the high self employed percentage also indicates that many people will act to improve their QoL, through elective occupational options. For example, if QoL, as measured by job availability, is improving in a region, it is likely more people are drawn to the area. Figure 9 shows the mobility of the work force and job growth in areas of high amenities are both factors in determining patterns of development in this region.

From the detailed analysis (Table 8) in the study area, occupational status has an important role in quantifying QoL of the residents. It is seen that daily wage labours and self employed respondents have a "Significantly above Average" QoL (4\%) and (7\%) respectively. 100\% of the respondents who are employed have an "Average" QoL.

\subsubsection{Level of Education}

This changing pattern of industrial production and expanding work force has its own implications for the workers in this region. With this abundance of labour, in a resource rich region it is relatively easy to find men, women and children to take up ill-paid and unsafe jobs. The more deprived the social origin of the worker, the greater is the compulsion to take up any job irrespective of its hazards. Thus easy money from a hazardous job makes regions habitants reluctant towards better educational services. Here educational level was considered of importance because it is directly related to the quality of the workforce. Figure 10 shows $44 \%$ of the respondents are illiterate, only $31 \%$ of the respondents have primary level education, $17 \%$ have higher secondary level of education (Figure 10).

The QoL satisfaction level highly depends on the level of education and this is corroborated during this study as well. As seen in this is a potential explanation to the "Significantly above Average" QoL reported by a few respondents who are illiterate. The other set of "Significantly above Average" QoL are the people who have the highest level of education and this is noted to be the set of people also having "Significantly above Average" satisfaction level in Economic Domain. This confirms that education is indeed an enabler for economic prosperity and over all better QoL.

$100 \%$ of the Undergraduate population have "Significantly above Average" QoL. 92\% of the population who have studied up to higher secondary courses have "Average” QoL. 50\% of the respondents having completed secondary school have “Above Average” QoL.

Table 8. Occupational status and quality of life.

\begin{tabular}{cccccc}
\hline \multirow{2}{*}{ Occupational Status } & \multicolumn{5}{c}{ Quality of Life } \\
\cline { 2 - 6 } & Significantly below Average & Below Average & Average & Above Average & Significantly above Average \\
\hline Overall Population & $0 \%$ & $15.7 \%$ & $70.0 \%$ & $8.6 \%$ & $5.7 \%$ \\
Daily Wage Labour & $0 \%$ & $30.4 \%$ & $60.9 \%$ & $4.3 \%$ & $4.3 \%$ \\
Employed & $0 \%$ & $0 \%$ & $100.0 \%$ & $0 \%$ & $0 \%$ \\
Self Employed & $0 \%$ & $9.3 \%$ & $72.1 \%$ & $11.6 \%$ & $7.0 \%$ \\
\hline
\end{tabular}

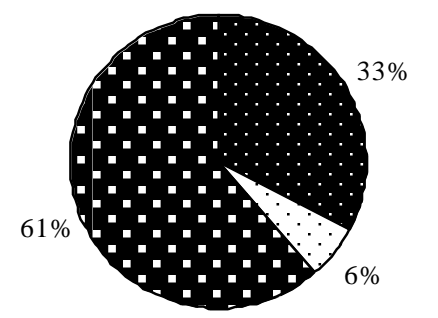

\section{Type of Occupation}

- Daily Wage Labour

$\square$ Employed

- Self Employed

Figure 9. Distribution of occupation. 


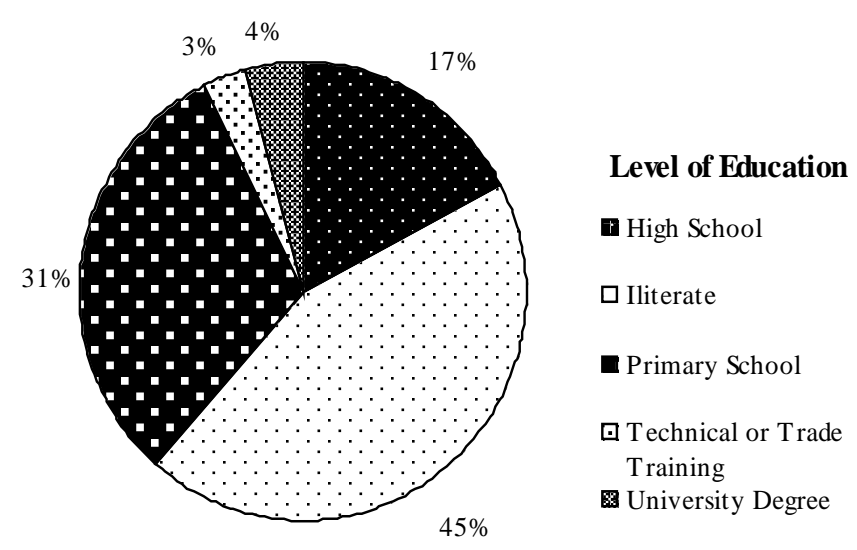

Figure 10. Distribution of occupation.

Predictably, the illiterate respondents show an n opposite phenomenon where $29 \%$ illiterate population have "Below Average" QoL and this group is what accounts for most of the overall "Below Average" QoL. Table 9 shows that respondents with no education tend to have lesser understanding and knowledge about the world beyond their location of stay and seem to be content with lesser attainments.

This is a potential explanation to the "Significantly above Average" QoL reported by a few respondents who are illiterate. The other set of "Significantly above Average" QoL are the people who have the highest level of education and this is noted to be the set of people also having "Significantly above Average" satisfaction level in Economic Domain. This confirms that education is indeed an enabler for economic prosperity and over all better QoL.

\subsection{Analysis of Domain Based Quality of Life}

QoL Domains are standardized measures with which to monitor and compare the QoL of a group or population. The approach taken in this paper was to select a list of formative indicators from each of the selected domains and was included in a QoL questionnaire.

One of the important outcomes of this research is the identification of QoL Predictors-those domains that seem to impact the perceptions of QoL in each community and for the respondents as a whole. Hence this section of the paper deals with individual domain and its correlation with Total QoL of the group of respondents.

A Heat Map is generated to visually depict the dependency of individual domain on the Total QoL. The X axis has the domain scores in the 5-point scale (SBA, BA, A, AA, SAA) ${ }^{1}$ while Y axis contains the Average QoL score in the 5-point scale. Additionally, a simple regression equation has been developed demonstrating the correlation between the domain and the Total QoL.

\subsubsection{Economic Liberty Domain}

Economic issues such as income and wealth are significant in quantifying QoL. The prospect of a higher income has been identified as a major factor in motivating people to move to such communities [16] [17]. The economic domain includes aspects of one's monetary life and material wealth. This section focuses on the economic aspects of the respondents QoL. Domain questions asked about the adequacy of financial support and satisfaction with the amount of control he/she has over those financial resources in case of saving for the future. From the Figures 8-10, it shows less than 5\% of the surveyed respondents have Average QoL in economic domain and reports to be having Below Average Total QoL. Higher the economic domain satisfaction ensures higher Total QoL. A small percentage of respondents rating themselves to be "Significantly above Average" in economic domain rate their Total QoL as "Above Average”, "Average” and "Significantly Above Average”. More than 50\% of respondents having average satisfaction in economic domain have "Average” Total QoL and more than 5\% respondents having "Below Average" economic liberty domain satisfaction have Average Total QoL score as shown in Figure 11.

\footnotetext{
${ }^{1}$ SBA—Significantly below Average QoL; BA—Below Average QoL; A—Average QoL; AA—Above Average QoL; SAA—Significantly above Average QoL.
} 
Table 9. Level of education and quality of life.

\begin{tabular}{|c|c|c|c|c|c|}
\hline \multirow{2}{*}{ Level of Education } & \multicolumn{5}{|c|}{ Quality of Life } \\
\hline & Significantly below Average & Below Average & Average & Above Average & Significantly above Average \\
\hline Overall Population & $0 \%$ & $15.7 \%$ & $70.0 \%$ & $8.6 \%$ & $5.7 \%$ \\
\hline High School & $0 \%$ & $0 \%$ & $92 \%$ & $8 \%$ & $0 \%$ \\
\hline Illiterate & $0 \%$ & $29 \%$ & $65 \%$ & $3 \%$ & $3 \%$ \\
\hline Primary School & $0 \%$ & $9 \%$ & $77 \%$ & $14 \%$ & $0 \%$ \\
\hline Technical or Trade Tranning & $0 \%$ & $0 \%$ & $50 \%$ & $50 \%$ & $0 \%$ \\
\hline University Degree & $0 \%$ & $0 \%$ & $0 \%$ & $0 \%$ & $100 \%$ \\
\hline
\end{tabular}

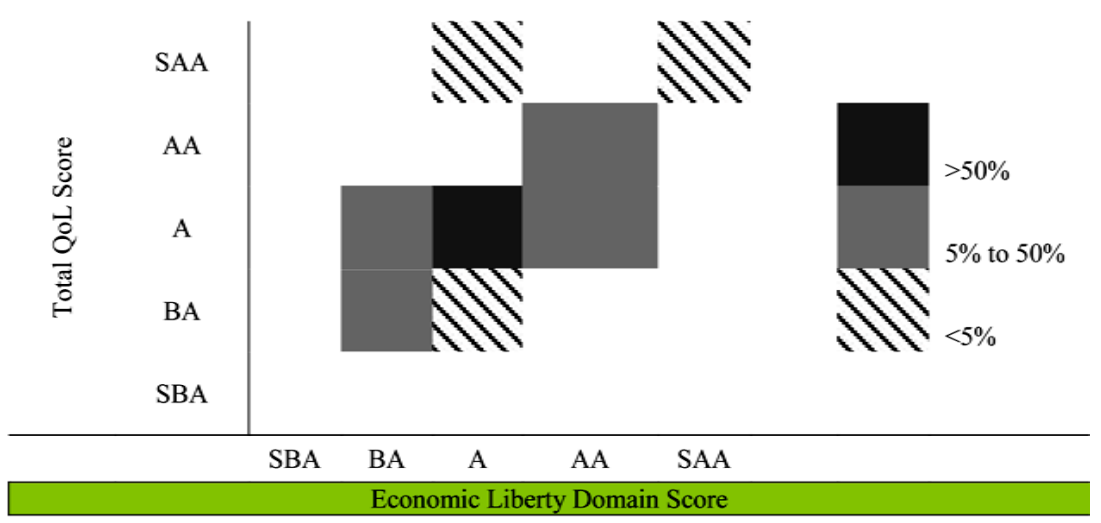

Figure 11. Heat map of economic liberty domain satisfaction with Total QoL.

Figure 12 the scatter diagram in the graph along with the regression equation above shows a strong correlation between respondents' satisfaction with life and financial security and stability. Statistically, the correlation value between Economic Liberty score and Total QoL is 0.899 indicating a strong correlation between the two. Higher the Economic score, higher would be the Total QoL.

\subsubsection{Environmental Liberty Domain}

The environment domain includes the following indicators: social security, development schemes, access to nature, cleanliness and security, basic infrastructure, services and goods available and transportation options. However, statistically, satisfaction with the environmental domain does not uniquely predict satisfaction with QoL. It is clear from the literature review, qualitative analysis and participant observation that environmental aspects are of critical importance to QoL in general [18] [19].

Most of the participants in this research mentioned environmental qualities as a significant determinant of satisfaction with QoL in their region with more than 50\% of the respondents who scores Average satisfaction in environmental domain also have "Average” Total QoL score. Figure 13 shows the total quality of life in environmental domain.

As depicted in Figure 14 the heat map, there is a lot of scatter in environment scores and Total QoL scores e.g. there is a small population, less than 5\%, for whom a "Significantly Average" Environment score does not result in more than “Average” Total QoL. Statistically, the correlation value between Environmental Liberty score and Total QoL is 0.590 indicating a moderate correlation between the two.

\subsubsection{Community Liberty Domain}

This section focuses on respondent's perceived ability to perform accustomed functions and social activities of daily living including relationship with neighbour, and related factors included for community living.

As shown in the Figure 15 and Figure 16, more than 50\% of the respondents having "Average” score in 


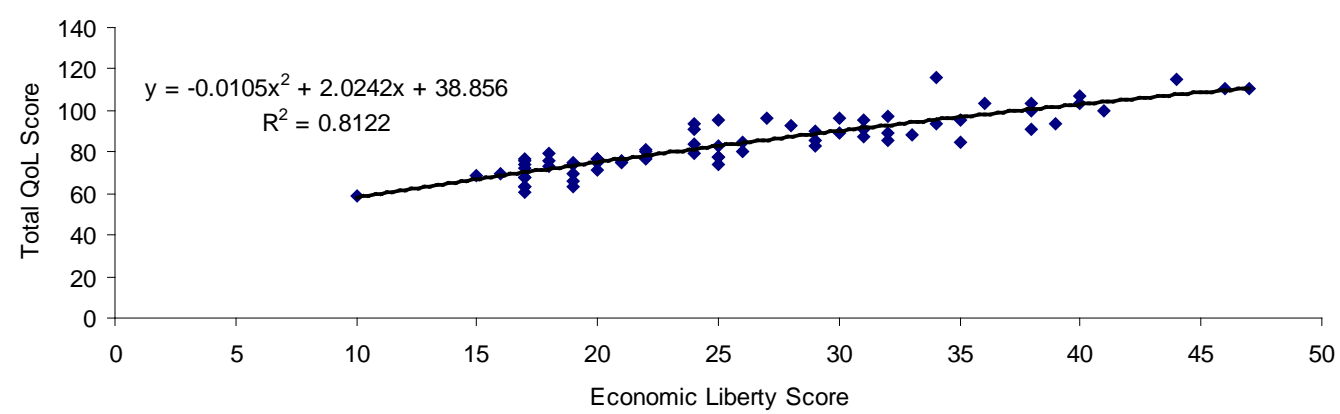

Figure 12. Scatter plot of total quality of life with economic liberty domain.

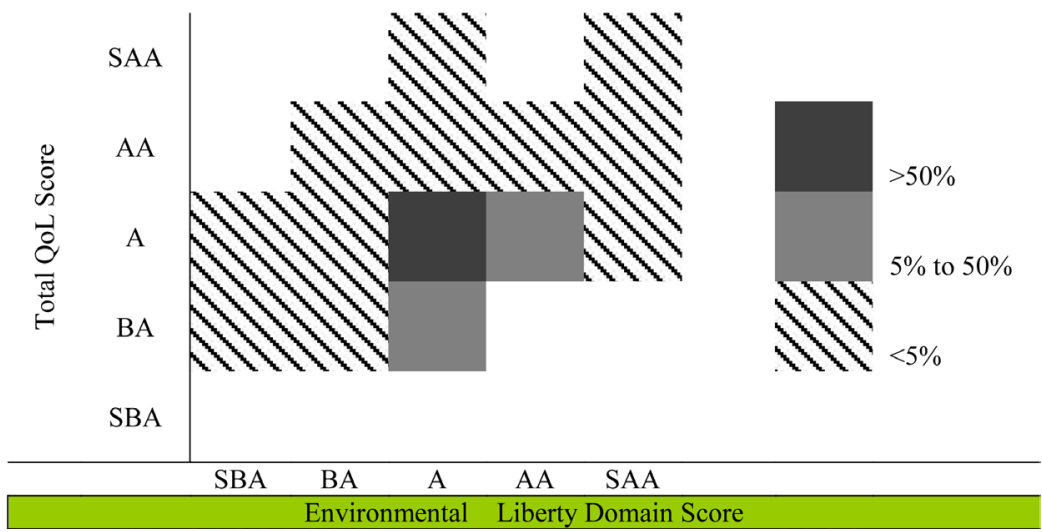

Figure 13. Heat map of economic liberty domain satisfaction with Total QoL.

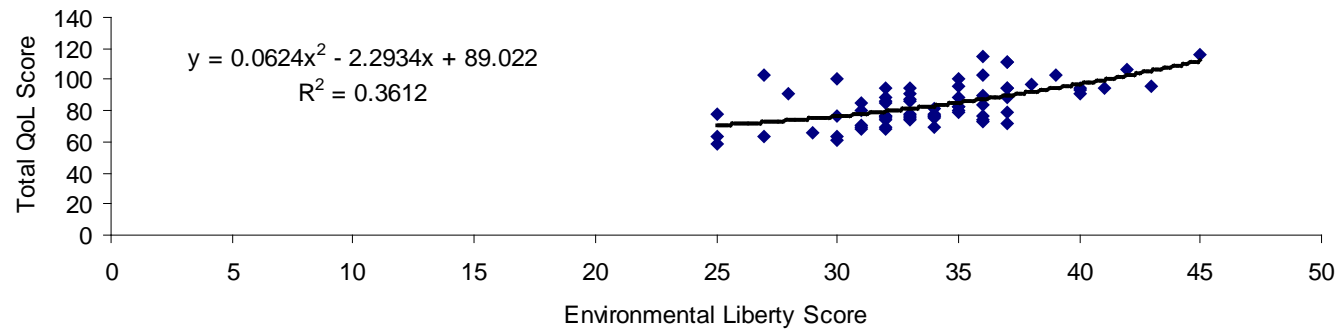

Figure 14. Scatter plot of total quality of life with environmental liberty domain.

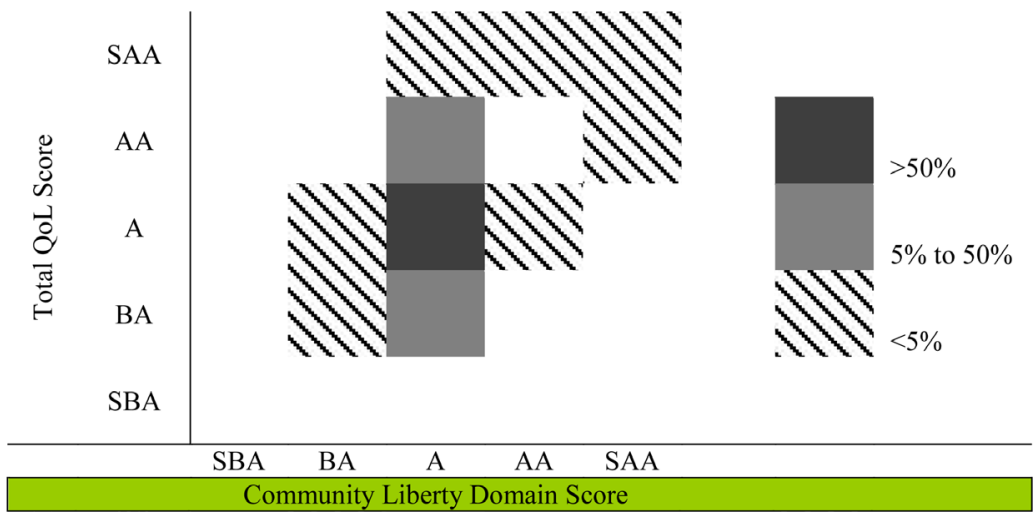

Figure 15. Heat map of community liberty domain satisfaction with Total QoL.

community liberty domain also have Average Total QoL. The heat map scatter is similar to environment domain with lesser correlation e.g. a small population of less than $5 \%$ respondents having Average Community score but 
having "Significantly above Average" Total Score. Similarly few respondents who are Above Average in the scores of Community Liberty have an Average QoL. Statistically, the correlation value between Community Liberty score and Total QoL is 0.563 indicating a moderate correlation between the two like that of Environmental Liberty.

\subsubsection{Civil Liberty Domain}

The civil liberty domain includes indicator related to various facilities in the civil society. However, from the survey of the study area it is evident that the residents of the region who are deprived of services are not satisfied with the civil liberty domain. Human being are concerned about several categories which cover individuals' concern about income, assets, health, and leisure opportunities, while other categories are aimed at concerns typically entrusted to governments such as ensuring the vivacious condition of a community. The study population is from the deprived sections of the society struggling with basic needs and their needs correspond to the bottom three levels of Abraham Maslow's theory of Hierarchy of Needs namely Physiological, Safety and Social needs basic needs. Unlike the previous 3 domains, Civil Liberty scores are well spread with Total QoL scores with no particular Civil Liberty score accounting for more than 50\% population as shown in Figure 17.

Figure 18 a scatter diagram in the graph along with the regression equation above shows a moderate correlation which is corroborated statistically with a correlation value of 0.631 between civil liberty score and Total QoL. This score, incidentally, higher than the correlation for Environmental and Community domains.

\subsubsection{Correlation among the Four Quality of Life Domains}

As shown in Table 10, although the correlation between the individual domains and Total QoL range from moderate to strong correlation, the inter-domain correlations are significantly weak. Economic liberty domain and civil liberty domain share the highest inter-domain correlation of 0.457 .

\section{Distribution of Overall Quality of Life Score}

Overall QoL is the self rated satisfactory score given by the respondents themselves when asked "How do they rate their life" on a Likeret scale of 0 - 10. Figure 19 shows the percentage of respondents rating their OQoL.

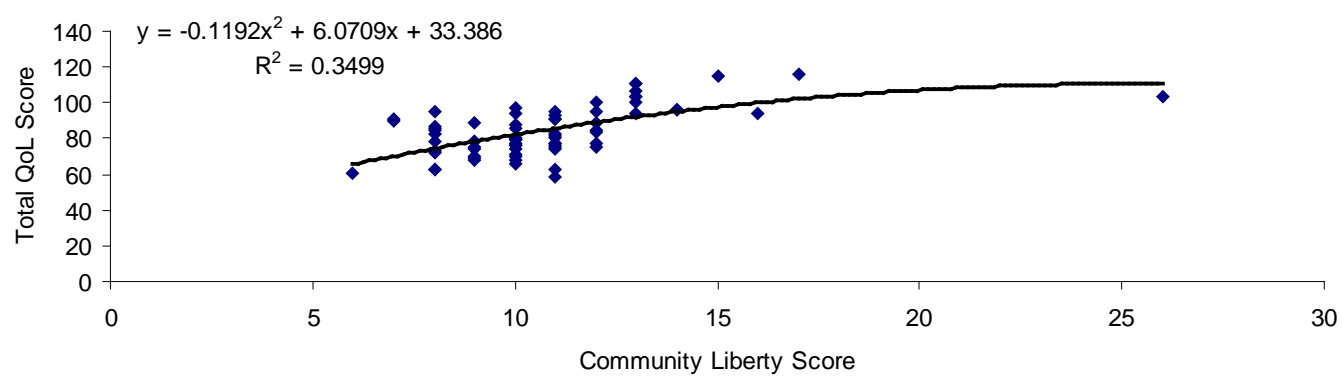

Figure 16. Scatter plot of total quality of life with community liberty domain.

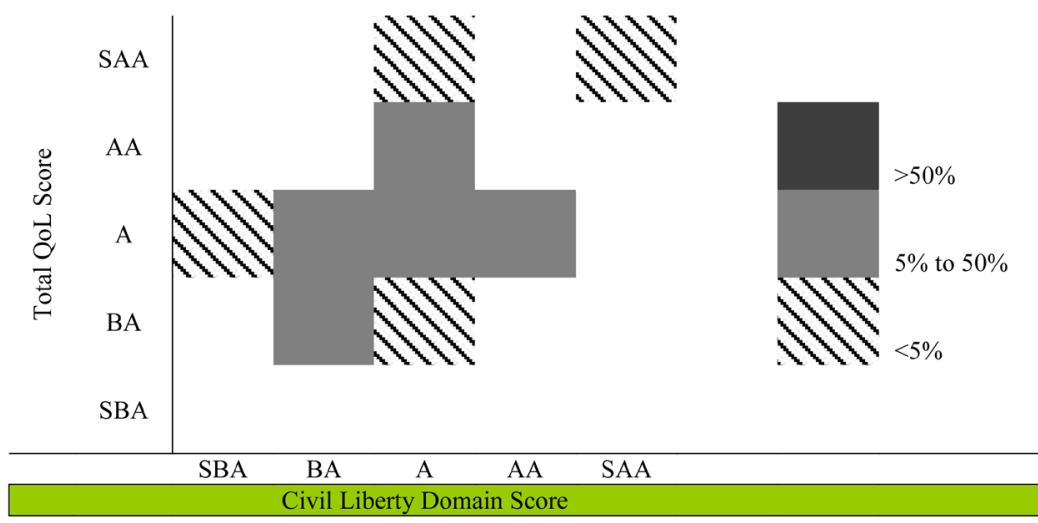

Figure 17. Heat map of civil liberty domain satisfaction with Total QoL. 


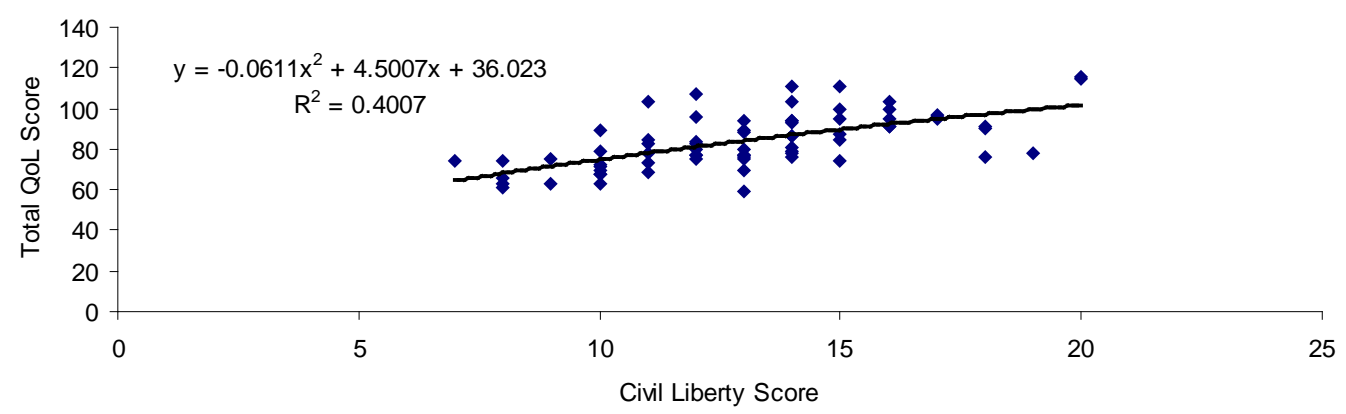

Figure 18. Scatter Plot of total quality of life with civil liberty domain.

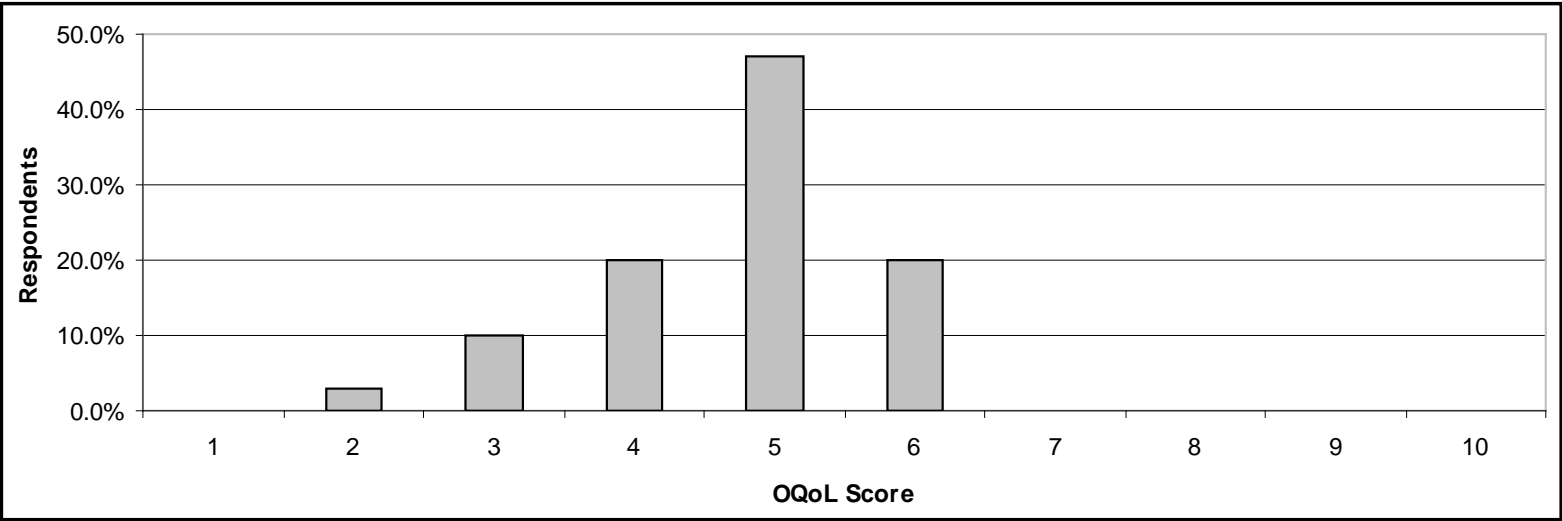

Figure 19. Overall quality of life score distribution.

Table 10. Correlation between domains and total quality of life scores.

\begin{tabular}{ccccccc}
\hline \multirow{2}{*}{ Liberty Domain } & \multicolumn{5}{c}{ Domain Wise Correlation Score } \\
\cline { 2 - 6 } & Economic & Environmental & Community & Civil & Total QoL \\
\hline Economic & 1.000 & 0.312 & 0.357 & 0.457 & 0.899 \\
Environmental & - & 1.000 & 0.226 & 0.214 & 0.590 \\
Community & - & - & 1.000 & 0.279 & 0.563 \\
Civil & - & - & - & 1.000 & 0.631 \\
Total QoL Score & - & - & - & - & 1.000 \\
\hline
\end{tabular}

It may be noted that $67 \%$ of the population or two-thirds of the population had the view that they have an Overall QoL perception greater than or equal to a "Neutral" score of 5. The overall mean score for the population is 4.7. This is in contrast with the individual mean scores of the domains (economical liberty 2.184, environmental liberty 3.766, community liberty 2.163, and civil liberty 2.183). This demonstrates that although on a single question baseline of OQoL a person might have a better impression of his/her QoL but when questioned on deeper sub-elements which comprise the QoL, the individual domain scores dip lower than the overall impression.

The Table 11 shows the correlation between OQoL rated by the respondents with respect to individual QoL domains. The Total QoL score as a summation of the domain scores has a strong correlation with the OQoL as expected. Similarly, the Economic Liberty score shows the strongest correlation amongst the domains. Following it is the higher moderate correlation between the Environmental score and OQoL. For community and civil liberty domains there is a low correlation with OQoL. This demonstrates that people's perception about overall QoL is strongly driven by economic well-being and environmental well-being to an extent while community and civil matters are not strongly correlated. 
Table 11. Correlation of domains score and overall quality of life.

\begin{tabular}{cc}
\hline Domains Score & Overall Quality of Life \\
\hline Total QoL Score & 0.716 \\
Economic Liberty Score & 0.665 \\
Environmental Score & 0.557 \\
Community Liberty Score & 0.301 \\
Civil Liberty Score & 0.304 \\
\hline
\end{tabular}

\section{Path Analysis for Overall Quality of Life Measure}

Figure 20 displays a path analysis which shows a causal progression from top to bottom and then towards left. The numbers on the arrows are path coefficients and indicate the strength of the relationship. Overall satisfaction with life is the final dependent variable.

People's response indicates that the path coefficients derived from the selected model demonstrates at economic and environmental domains having a greater influence on the OQoL. The more important of the two is economic domain: a higher level of satisfaction on one's economic domain reflects upon the overall subjective QoL of the person. This observation is strengthened by the high correlation and moderately high path coefficient (0.518605).

The second is the environmental domain: the greater the quality of the environment which have been explained by having better social security in the community, cleanliness and quality of surrounding the respondents live in, availability of public utilities like market, bank, hotel facilities, communication facilities like post office, telephones, mobile connectivity and pollution level in the environment (air, water, noise, soil). Therefore greater the respondents are satisfied with the above conditions higher the overall life quality. This is substantiated by the moderate path coefficient (0.38707) among environmental liberty domain and overall QoL.

Community liberty has nominal impact on overall QoL with low path coefficient (0.07319). At the same time economic domain has greater impact on community liberty domain with 0.3570 as path coefficient. Therefore respondent's higher satisfaction towards economic domain reflects higher satisfaction towards over all life. Civil liberty is influenced by OQoL as demonstrated by the negative path coefficient between the civil liberty domain and the overall QoL. It also demonstrates how the economic liberty domain has an overarching influence on OQoL as also having indirect impact on OQoL through its influence on other domains. The OQoL score has a moderate correlation with economic and environmental liberty and a low moderated correlation with community and civil liberty. Within the domains there is a moderate correlation between economic and civil liberty while other correlations are significantly weak.

As indicated by the path coefficients findings from the model indicate that for the entire sample population, mostly the environmental and the economic domains were predictors of satisfaction with life as a whole. The relative impact of community liberty domain on the overall QoL is limited compared to economic and environment domains and this reflects the fact that education, health facilities, transport facilities mean little compared to economic liberty parameters like income, work, eating habits and environmental parameters. The path coefficient of civil liberty with OQoL is negative and signified a reverse causal impact i.e. higher OQoL usually would result in greater satisfaction with civil liberty parameters like political stability equal opportunities and relationship with neighbours.

The path model establishes the fact that economic upliftment of the area will enable greater satisfaction in the economic liberty domain. This has a cascading effect on other domains and this is reflected in the following results of direct and indirect effect of economic liberty domain on overall QoL.

Direct effect of Economic Liberty domain on OQoL $=P_{01}=0.5186$.

Indirect effect of Economic Liberty domain on OQoL $=\left(P_{21} P_{02}\right)+\left(P_{31} P_{03}\right)+\left(P_{41} P_{04}\right)=0.1467$.

Total effect of Economic Liberty domain on OQoL $=$ Direct effect + Indirect effect $=0.6653$.

This shows that indirect effect of economic liberty through environmental, civil and community liberty domains is $22 \%$ which is significant. Further this means that every 1.0 standard deviation increase in economic liberty score leads to a 0.6653 standard deviation increase in OQoL. The correlation achieved between the path 


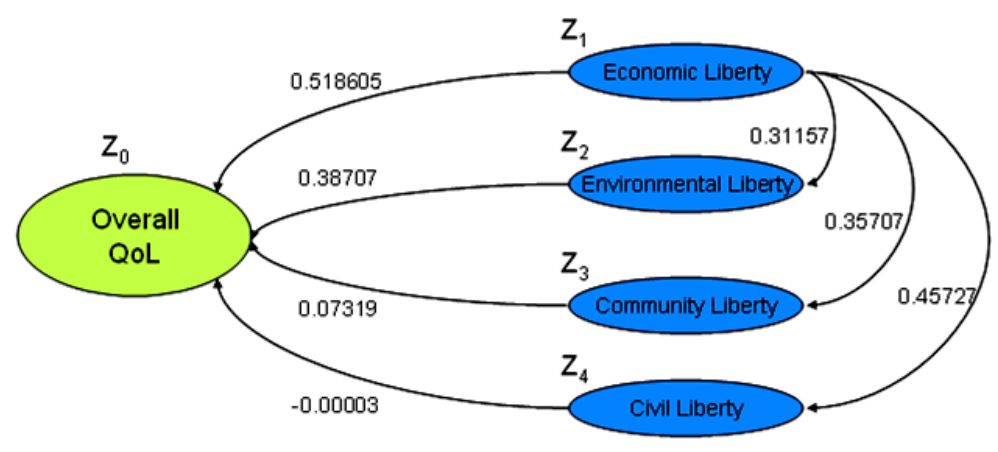

Figure 20. Path model of overall quality of life (OQoL).

model regression equations and the OQoL has a strong correlation value of 0.7437 which is higher than the correlation derived from other path models used during the evolution to the final path model.

These findings indicate that in order to impact satisfaction with life as a whole in the region, close attention must be given to economic and environment related aspects of life.

\section{Conclusions}

It was seen that $70 \%$ respondents in the JCR reported to have average QoL in the range of 2.20 to 3.05 for that region which is below the QoL Likert scale of 5 for "Satisfied".

The opportunities in the study that exist today are indicative of the change in order to improve the QoL. Such opportunities include the changing economic and civil cultures in the region; strong environmental and community services; and academic institutions that are dedicated to the improvement of the biophysical, economic, and social conditions. However, these possibilities alone will not create a healthier, region. The domain wise approach towards accessing QoL and integrating environmental, social, economic liberty information is to better inform decision makers of the implications and benefits of alternate courses of action are compatible with each other. The main value of integration of indicators in these differing realms is to get a more complete picture of contemporary society.

The impact the mining on local people depends on the resource available to and conditions faced by the local people who follow mining activities. Mining activity has to ensure that there is improved QoL giving emphasis on the social, environmental and health impacts of mining and the implications of resource demand of mining vis-à-vis the rights and needs of the people.

The Path Model establishes the fact that economic upliftment of the area will enable greater satisfaction in the economic liberty domain. This has a cascading effect on other domains and this is reflected in the direct and indirect effect of economic liberty domain on OQoL. Path Analysis will helps us with establishing a hypothesis on the causal effect of the various parameters on OQoL. With the selected path model, it is established that Economic domain has the highest influence on OQoL while it also has a causal effect on Environmental and Community Domains. Environmental domain is the second most influencer of OQoL while civil liberty domain has a negative path coefficient indicating that OQoL influences Civil Liberty than the other way around. This shows that indirect effect of Economic Liberty through environmental, civil and community liberty domains is $22 \%$ which is significant. Further this means that every 1.0 standard deviation increase in Economic Liberty score leads to a 0.6653 standard deviation increase in OQoL. The correlation achieved between the path model regression equations and the OQoL has a strong correlation value of 0.7437 which is higher than the correlation derived from other path models used during the evolution to the final path model.

It can be concluded from the study that QoL is a multidimensional concept and the dimension that emerged in the form of domains like-conomic Liberty, Environmental Liberty, Civil Liberty and Community Liberty. The study helped to standardize the questionnaire tool to assess the QoL of residents of the problem area and also to suit the Indian scenario. Findings indicate that in order to impact satisfaction with life as a whole in the mining region, close attention must be given to economic and environment related aspects of life.

Illustration from the study area reveals details of the environmental and living conditions of the families. Government over years has tried to relocate affected families but have failed. In this research QoL analysis shows that the residents of this region though very satisfied with the economic facet of their individual life's but 
are highly dissatisfied with the environmental community facets of living. Looking in the vulnerable conditions several suitable rehabilitation and relief for coal-fire families have been planned. In one of the biggest rehabilitation plans in the world, the centre has announced to launch a scheme to relocate to safer areas some 79 thousands families whose houses face the threat of being sucked in by underground fires raging for the last 40 years (TOI, 2009).

CSR (Corporate Social Responsibility) for the local community has to be implemented. Coal India the major coal mining company and other industrial units should give more than $50 \%$ of their profit in CSR activities. Jharia coalfields industrial units are dominated by big industrial corporate houses both in private (Tata's) and public sectors like Bharat Coking Coal Company Ltd are integral part of CIL unit.

For the deterioration in the quality of life and for improvement these industries have a major role to play in the study area. Keeping this in view, Government of India through MOEF and MORD and others have taken special interest in Corporate Social Responsibility. Towns and villages within the buffer zones of $(10 \mathrm{~km})$ radius have been taken into consideration for Community Development Programme. The implementation of CSR will have environmental benefits like greater material recyclability, better product durability and function ability, greater use of renewable resources and integration of environmental management tools into business plans, management standards and ecolabeling processes.

\section{References}

[1] Karunakaram, C. (1982) Role of Environmental Geology in Environmental Planning for Mining Operations. Proceedings of National Seminar on Minerals and Ecology, Delhi, 16-18 February 1982.

[2] Michalski, S.R. (2004) The Jharia Mine Fire Control Technical Assistance Project: An Analysis. International Journal of Coal Geology, 59, 83-90. http://dx.doi.org/10.1016/j.coal.2003.11.005

[3] Schori, A., Scrymgeour, A.H. and Munshi, P.L. (1997) Environment Management Plan for the Jharia Coalfield. Proceedings 14th Annual Meeting of the American Society for Surface Mining and Reclamation, (CD-ROM), Austin, 10-15 May 2004.

[4] Areeparampil, M. (1996) Displacement Due to Mining in Jharkhand. Economic and Political Weekly, 31, 1524-1528 http://www.jstor.org/stable/4404276

[5] Sarkar, B.C., Mahanta, B.N., Saikia, K., Paul, P.R. and Singh, G. (2007) Geo-Environmental Quality Assessment in Jharia Coalfield, India, Using Multivariate Statistics and Geographic Information System. Environmental Geology, 51, 1177-1196. http://dx.doi.org/10.1007/s00254-006-0409-8

[6] Pal, A.K. and Kumar, U.C. (2005) Quality Of Life (Qol) Concept for the Evaluation of Societal Development of Rural Community in West Bengal, India. Asia-Pacific Journal of Rural Development, XV, 2.

[7] Mishra, P.C., Mishra, B K. and. Tripathy, P.K. (2008) Socio-Economic Profile and Quality of Life Index of Sample Households of Mining Areas in Talcher and Ib Valley Coal Mines in Orissa. Journal of Human Ecology, 23, 13-20.

[8] Rapant, S., Dietzová, Z. and Cicmanova, S. (2006) Environmental and Health Risk Assessment in Abandoned Mining Area, Zlata Idka, Slovakia. Environmental Geology, 51, 387-397. http://dx.doi.org/10.1007/s00254-006-0334-x

[9] Saxena, N.C., Pal, A.K., Prusty, B.K. and Kumar, P. (1998) Quality of Life Index of the Mining Area. Special Issue on Environment of the Indian Mining and Engineering Journal, Centre of Mining Environment, Indian School of Mines, Dhanbad, 15-18 July 1998.

[10] Saxena, N.C., Pal, A.K., Kumar, P. and Prusty, B.K. (1997) Quality of Living in Indexing for Mining Complexes in India. 2nd World Mining Congress, Katowice.

[11] Kumar, P. (1996) Socioeconomic Profile of West Bokaro Mining Complex. M.Tech Dissertation, Indian School of Mines, Dhanbad.

[12] Prusty, B.K. (1996) An Investigation into the Socio-Economic Profile of Bhowra Area of Jharia Coal-Fields. M.Tech Dissertation, Indian School of Mines, Dhanbad.

[13] Chakraborty, T. and Ghosh, A.K. (2005) Need and Prospect of R\&R in Jharia Coalfield. Conference on Technological Advancement and Environmental Challenges in Mining and Allied Industries in the 21st Century, Rourkela, 5-6 February 2005.

[14] Government of India (1998) Carrying Capacity Based Developmental Planning of Damodar River Basin. Published in Alternative Scenario, Volume II, Sponsored by Ministry of Environment and Forest, New Delhi.

[15] Michalski, S.R. (2004) The Jharia Mine Fire Control Technical Assistance Project: An Analysis. International Journal of Coal Geology, 59, 83-90. http://dx.doi.org/10.1016/j.coal.2003.11.005

[16] Riffel, J.A. (1975) Quality of Life in Resource Towns. Urban Affairs, Ottawa. 
[17] Sibbel, A.M., Sibbel, J. and Goh, K. (2006) Fly-In, Fly-Out Operations-Strategies for Managing Employee WellBeing. Proceedings of the International Mine Management Conference, Australasian Institute of Mining and Metallurgy (Ausimm), Melbourne, 16-19 October 2006.

[18] Takaro, T., Nakamura, K. and Watanabe, M. (2002) Urban Residential Environments and Senior Citizens' Longevity in Megacity Areas: The Importance of Walkable Green Spaces. Journal of Epidemiology and Community Health, 56 913-918.

[19] Sarvan, E. (2006) Life in The City—Innovative Solutions for Europe’s Urban Environment. European Communities, Luxembourg. 
Scientific Research Publishing (SCIRP) is one of the largest Open Access journal publishers. It is currently publishing more than 200 open access, online, peer-reviewed journals covering a wide range of academic disciplines. SCIRP serves the worldwide academic communities and contributes to the progress and application of science with its publication.

Other selected journals from SCIRP are listed as below. Submit your manuscript to us via either submit@scirp.org or Online Submission Portal.
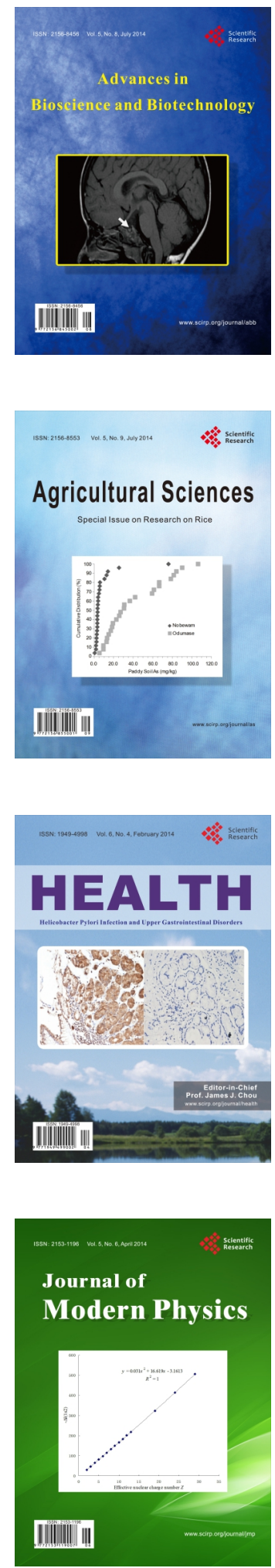
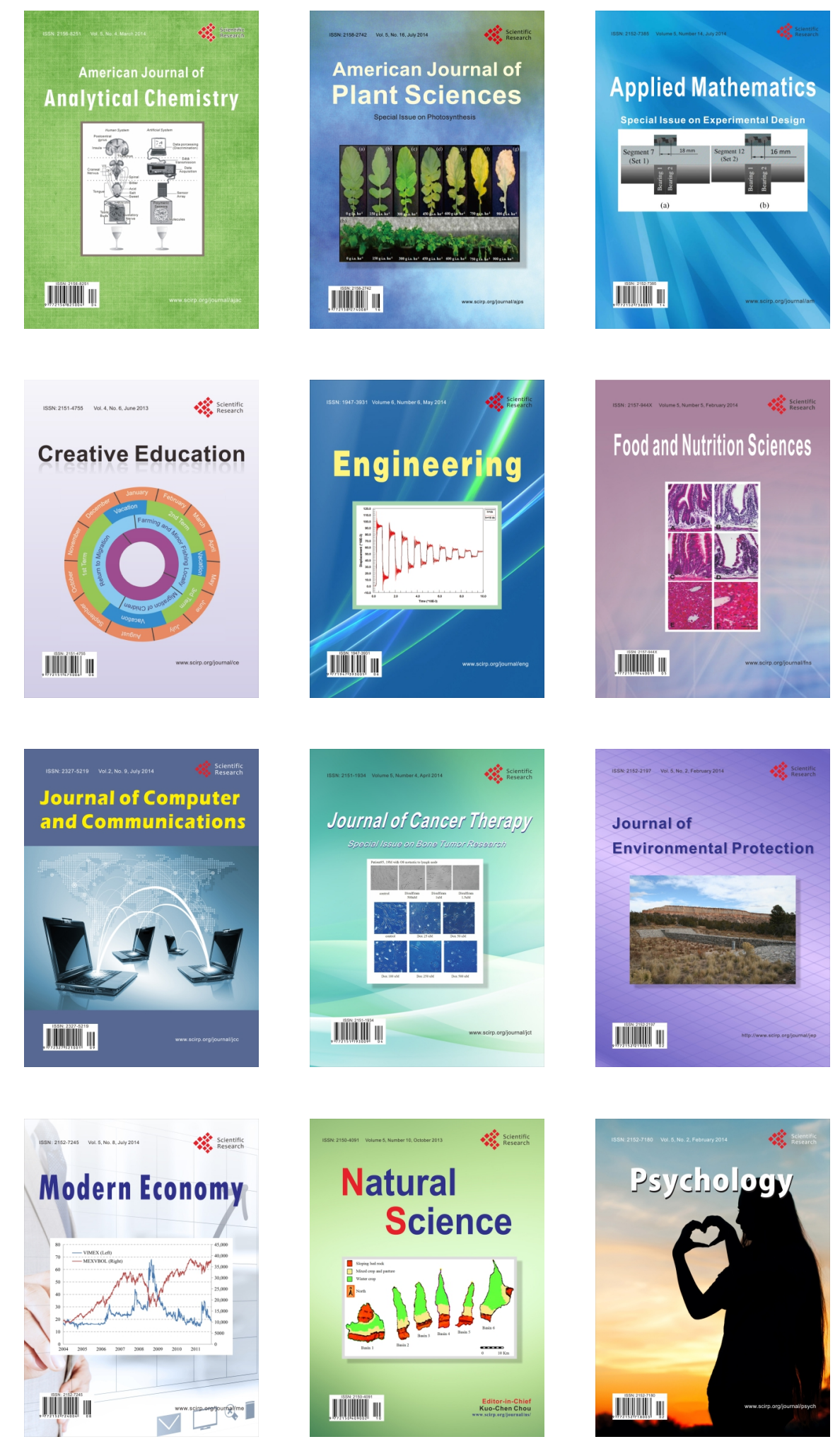